\title{
The Separation of Fe from Ga to Produce Ultrapure ${ }^{67} \mathbf{G a}$
}

\author{
Nicholas P. van der Meulen and Tjaart N. van der Walt \\ iThemba LABS, P.O. Box 722, Somerset West, 7129, South Africa \\ Reprint requests to N.P. van der Meulen. Fax:+27 21 8433901. E-mail: nick@tlabs.ac.za
}

Z. Naturforsch. 2007, 62b, 483-486; received December 5, 2006

Dedicated to Prof. Helgard G. Raubenheimer on the occasion of his $65^{\text {th }}$ birthday

\begin{abstract}
The production of ${ }^{67} \mathrm{Ga}$ at iThemba LABS is performed by the proton bombardment of a tandem ${ }^{\text {nat }} \mathrm{Zn} /{ }^{\text {nat }} \mathrm{Zn}$ target. ${ }^{67} \mathrm{Ga}$ is separated from the target material using a method based on target dissolution, in acidic media, and dual chromatographic methods on Amberchrom CG-161M. The result is a product with a high radionuclidic purity ${ }^{67} \mathrm{Ga}$ having such a low $\mathrm{Fe}$ content in the final product that it may be used in the labelling of peptides.
\end{abstract}

Key words: ${ }^{67} \mathrm{Ga}, \mathrm{Fe}$, Purification, Ion Exchange

\section{Introduction}

${ }^{67} \mathrm{Ga}\left(t_{1 / 2}=78.3 \mathrm{~h}\right)$, which is produced in a cyclotron and decays to stable ${ }^{67} \mathrm{Zn}$, is extensively used in nuclear medicine [1]. Its decay emissions have been identified as $\gamma$ rays of $93.3 \mathrm{keV}$ (37\% abundance), $184.6 \mathrm{keV}(20.4 \%$ abundance) and $300.2 \mathrm{keV}(16.6 \%$ abundance). It is usually separated from $\mathrm{Zn}$ by means of ion exchange chromatography [2,3] or by liquid extraction $[2,4]$. The product is predominantly supplied in the citrate form and used for imaging soft tissue tumours and abscesses.

When in citrate form, ${ }^{67} \mathrm{Ga}$ is known to concentrate in many types of tumours, as well as non-malignant lesions. Although it is not a tumour-specific agent [5], it is used extensively for the localisation of a variety of human malignant tumours $[6,7]$ and, due to its widespread application as a diagnostic tool in nuclear medicine, ${ }^{67} \mathrm{Ga}$ is one of the most widely employed cyclotron-produced radiopharmaceuticals.

A number of routes for the production of ${ }^{67} \mathrm{Ga}$ in large quantities, and their development into medical applications, have been reported [8-13]. Several methods have been performed to separate ${ }^{67} \mathrm{Ga}$ from its target material by different ion exchange methods $[14-18]$ and to use the product in citrate form for medical applications.

The current production method used at iThemba LABS involves the bombardment of two ${ }^{\text {nat }} \mathrm{Zn}$ targets, in tandem, with the use of a $66 \mathrm{MeV}$ proton beam provided by the facility's separated sector cyclotron. The bombarded targets are dissolved in hydrochloric acid and the resultant solution passed through a column containing Amberchrom CG-71cd resin. Any impurities contained on the resin are eluted, before the ${ }^{67} \mathrm{Ga}$ is eluted as the final product.

While the final product is deemed suitable for use in diagnostic nuclear medicine, the product has failed to label certain peptides efficiently. The theory is that certain ${ }^{67} \mathrm{Ga}$-labelled peptides may be effective for therapeutic purposes, thus, it was decided to investigate the possibility of producing an ultrapure product, such that this theory can be tested.

While there have been descriptions of $\mathrm{Ga}$ and $\mathrm{Fe}$ separation from other elements [19-21] in the literature, they do not adequately describe how $\mathrm{Fe}$ and $\mathrm{Ga}$ can be separated easily, as Fe(III) and $\mathrm{Ga}$ (III) have very similar chemical properties. It was thought prudent to adapt the method currently used for production purposes at iThemba LABS.

\section{Experimental Section}

Analytical grade reagents were used throughout this work and were obtained from Merck (SA) Pty. Ltd or Sigma Aldrich $\mathrm{GmbH}$, which included Sigma, Aldrich, Fluka and Riedel de Haen products. The Chelex 100 chelating resin used in this work was obtained from BioRad Laboratories, Richmond, U.S.A., while the Amberchrom CG-161M resin was obtained from Rohm and Haas Company, Philadelphia, U.S.A. 


\begin{tabular}{lllllll}
\hline $\begin{array}{l}\text { Reducing } \\
\text { agent }\end{array}$ & $\begin{array}{l}\text { Product 1: } \\
\text { Fe content } \\
\left(\mu \mathrm{g} \mathrm{mL}^{-1}\right)\end{array}$ & $\begin{array}{l}\text { Product 2: } \\
\text { Fe content } \\
\left(\mu \mathrm{g} \mathrm{mL}^{-1}\right)\end{array}$ & $\begin{array}{l}\text { Percentage } \\
\text { removed }\end{array}$ & $\begin{array}{l}\text { Product 1: } \\
\mathrm{Zn} \text { content } \\
\left(\mu \mathrm{g} \mathrm{mL}^{-1}\right)\end{array}$ & $\begin{array}{l}\text { Product 2: } \\
\mathrm{Zn} \text { content } \\
\left(\mu \mathrm{g} \mathrm{mL}^{-1}\right)\end{array}$ & $\begin{array}{l}\text { Percentage } \\
\text { removed }\end{array}$ \\
\hline $\mathrm{SnCl}_{2}$ & 1.86 & 0.071 & 99.23 & 20.30 & 0.088 & 99.91 \\
$\mathrm{TiCl}_{3}$ & 4.44 & 0.010 & 99.92 & 32.50 & 0.412 & 99.58 \\
\hline
\end{tabular}

Table $1 . \mathrm{Fe}$ and $\mathrm{Zn}$ contents of samples using different reducing agents on Amberchrom CG-161M resin.

Wherever water is referred to in the experimental descriptions, de-ionised water was used. This was obtained by deionising tap water using a Millipore MilliQ Reagent Grade Water System to a conductivity of greater than $10 \mathrm{M} \Omega \mathrm{cm}^{-1}$.

All radioactive determinations were performed using a standard calibrated HPGe detector, with a relative efficiency of $8 \%$ (relative to three inch $\mathrm{NaI}$ ), connected to a multichannel analyser. All Fe and $\mathrm{Zn}$ determinations were performed using a Varian graphite furnace atomic absorption spectrophotometer.

A good reducing agent is necessary to perform the experiments successfully. Comparisons were made using $\mathrm{TiCl}_{3}$, $\mathrm{SnCl}_{2}$ and ascorbic acid using different conditions. While $\mathrm{TiCl}_{3}$ is a strong reducing agent, it contains traces of $\mathrm{Fe}$ when provided in $1 \mathrm{M} \mathrm{HCl}$ solution. As a result, the compound had to be purified, by means of cation exchange chromatography, prior to use.

Suprapur hydrochloric acid, which was used to perform the purification experiments with ${ }^{67} \mathrm{Ga}$, was provided by Merck (SA) Pty. Ltd.

\section{Reduction of $\mathrm{Fe}(\mathrm{III})$ with ascorbic acid}

${ }^{67} \mathrm{Ga}$ tracer was added to a $10 \mathrm{~mL}$ solution of $0.01 \mathrm{M}$ ascorbic acid containing $100 \mu \mathrm{g}$ Fe. This solution was passed through a $2.5 \mathrm{~mL}$ column containing Chelex 100 resin. Fe was eluted using $50 \mathrm{~mL}$ of $0.01 \mathrm{M}$ ascorbic acid, and the ascorbic acid was rinsed from the resin using $20 \mathrm{~mL}$ of water, before ${ }^{67} \mathrm{Ga}$ was eluted with $25 \mathrm{~mL} 2 \mathrm{M} \mathrm{HCl}$.

\section{Reduction of $\mathrm{Fe}(\mathrm{III})$ with $\mathrm{SnCl}_{2}$}

${ }^{67} \mathrm{Ga}$ tracer was added to $30 \mathrm{~mL}$ of a $0.1 \mathrm{M} \mathrm{HCl}$ solution containing $100 \mu \mathrm{g} \mathrm{Fe}$ and $2 \mathrm{~mL} \mathrm{S_{Cl }}(10 \mathrm{mg}$ in $10 \mathrm{~mL}$ of $1.0 \mathrm{M} \mathrm{HCl}$ ) and heated to $60{ }^{\circ} \mathrm{C}$, before an additional $35 \mathrm{~mL}$ of concentrated $\mathrm{HCl}$ was added to the solution. The resultant mixture was passed though a $2.5 \mathrm{ml}$ column containing Amberchrom CG-161M resin (although this was also tested with Amberchrom CG-71cd resin). The resin was rinsed with $100 \mathrm{~mL} 6 \mathrm{M} \mathrm{HCl}$ (to remove traces of $\mathrm{Fe}$ ), before the ${ }^{67} \mathrm{Ga}$ was eluted with $30 \mathrm{~mL}$ of $0.1 \mathrm{M} \mathrm{HCl}$, collecting $5 \mathrm{~mL}$ fractions.

\section{Reduction of $\mathrm{Fe}(\mathrm{III})$ with $\mathrm{TiCl}_{3}$}

Purified $\mathrm{TiCl}_{3}(3 \mathrm{~mL})$ was added to $30 \mathrm{~mL}$ of $0.1 \mathrm{M} \mathrm{HCl}$ solution containing $100 \mu \mathrm{g} \mathrm{Fe}$ and ${ }^{67} \mathrm{Ga}$ tracer. The solution was well mixed. A further $45 \mathrm{~mL}$ of concentrated $\mathrm{HCl}$ was added to the solution, before the resultant solution was passed through a $2.5 \mathrm{~mL}$ column containing Amberchrom CG-161M resin. The resin was rinsed with $50 \mathrm{~mL}$ of $6 \mathrm{M} \mathrm{HCl}$ (to remove traces of $\mathrm{Fe}$ and $\mathrm{Ti}$ ), before the ${ }^{67} \mathrm{Ga}$ was eluted with $30 \mathrm{~mL}$ of $0.1 \mathrm{M} \mathrm{HCl}$, by collecting $5 \mathrm{~mL}$ fractions of the final eluant.

\section{Results and Discussion}

The experiments, using ascorbic acid as a reducing agent, proved to be successful to a degree. Initial runs saw $93 \%$ of the ${ }^{67} \mathrm{Ga}$ removed in the first $10 \mathrm{~mL}$ of eluant, with an $88.3 \%$ removal of Fe. The subsequent runs, however, proved to be less successful, with much of the Fe appearing in the first aliquot of eluant fractions. It was determined that this could be due to the pump speed used for the experiments being too high. Even when the speed was decreased, however, the results did not improve much and this method was discarded.

The initial experiments involving $\mathrm{SnCl}_{2}$ proved to be unsuccessful, as no heat was involved in the experimental process. While the yield was impressive, $10 \mu \mathrm{g} \mathrm{mL}^{-1}$ of Fe was found in the final product, a quantity deemed inappropriate to regard the experiment as successful. According to distribution coefficients obtained by Naidoo [22], Ga(III) is better retained by Amberchrom CG-161cd (with a polystyrene/divinylbenzene matrix) than when using Amberchrom CG-71cd (with an acrylic ester matrix) as resin when the concentration of $\mathrm{HCl}$ increases. It was for this reason that most of the experiments performed on Amberchrom products were done using the CG-161 product, instead of the CG-71.

Subsequent experiments were performed by heating the solution to $60{ }^{\circ} \mathrm{C}$ before the addition of the concentrated $\mathrm{HCl}$. When using Amberchrom CG-161M, the results were found to be far more satisfactory, with $99 \%$ removal of $\mathrm{Fe}$ and virtually all the ${ }^{67} \mathrm{Ga}$ found in the first $10 \mathrm{~mL}$ of eluant (see Fig. 1). The same could not be said when using Amberchrom CG-71cd: the Fe removal from the final product decreased to $70 \%$, while $20 \mathrm{~mL}$ of eluant was required to quantitively remove the ${ }^{67} \mathrm{Ga}$ from the resin (see Fig. 2). 
Ga-67 on Amberchrom CG-161M

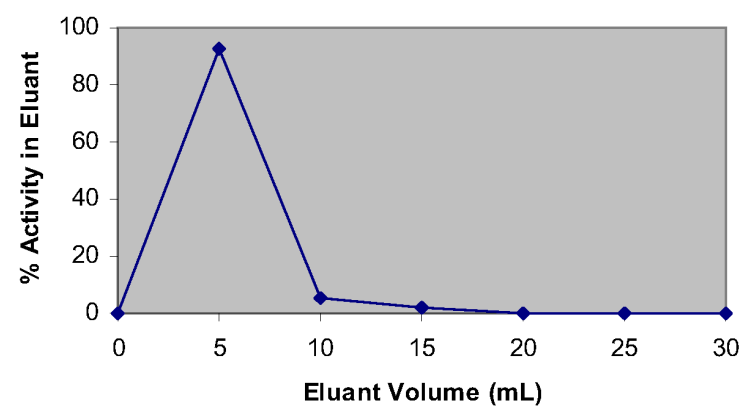

Fig. 1. Elution of ${ }^{67} \mathrm{Ga}$ from Amberchrom CG-161M using $0.1 \mathrm{M} \mathrm{HCl}$.

It was decided to perform a comparison between $\mathrm{SnCl}_{2}$ and purified $\mathrm{TiCl}_{3}$ as reducing agents. The results of the experiments using purified $\mathrm{TiCl}_{3}$ as a reducing agent with Amberchrom CG-161M resin also provided very promising results. No heat was required upon adding the reducing agent and the final product $\left({ }^{67} \mathrm{Ga}\right)$ was yielded in the first $10 \mathrm{~mL}$ of eluant, while removing more than $99 \%$ of the Fe added. With the results obtained from the comparison experiments, it was decided to take it a step further and perform a direct comparison under production simulation mode, that is, use a similar method as currently used in production and add the experimental method to it. This implies that a double column separation was performed.

The experiment was, thus, conducted as follows: two pressed $\mathrm{Zn}$ targets, weighing $c a .9 .46 \mathrm{~g}$, were dissolved in $60 \mathrm{~mL}$ of $32 \% \mathrm{HCl}$ (as used for routine production). Once complete dissolution was obtained a further $60 \mathrm{~mL}$ of $32 \% \mathrm{HCl}$, containing $3 \mathrm{~mL}$ purified $\mathrm{TiCl}_{3}$ solution, was added to the solution. The resultant mixture was passed through a column containing $2.5 \mathrm{~mL}$ Amberchrom CG-161M resin (100-200 mesh particle size and equilibrated with $7 \mathrm{M} \mathrm{HCl}) .150 \mathrm{~mL}$ of $7 \mathrm{M} \mathrm{HCl}$ was passed through the resin column to elute the impurities such as target material and traces of $\mathrm{Fe}$, before the ${ }^{67} \mathrm{Ga}$ was eluted with $30 \mathrm{~mL}$ of $0.1 \mathrm{M}$ Suprapur $\mathrm{HCl}$. Each experiment was then conducted further according to the method described above.

Samples were taken from the eluate of the first column $(30 \mathrm{~mL}$ of $0.1 \mathrm{M} \mathrm{HCl})$ and that of the second column, which was also the final product, and compared (see Table 1). As can be seen, the Fe and $\mathrm{Zn}$ contents in the first sample differ vastly between the experiments. This is due to the fact that no two $\mathrm{Zn}$ targets can have the same make up, thus, it was regarded as more pru-
Ga-67 on Amberchrom CG-71cd

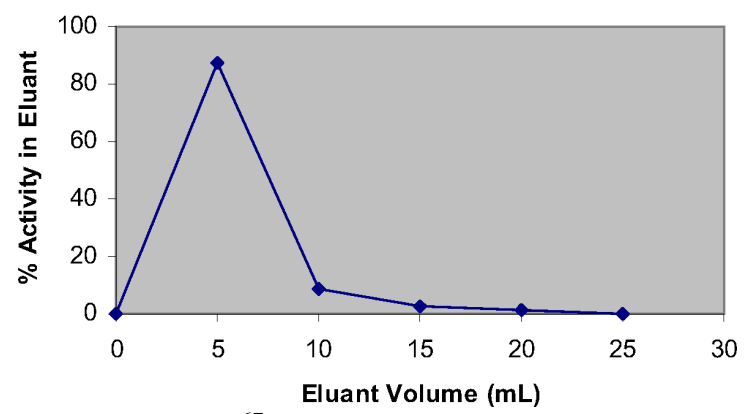

Fig. 2. Elution of ${ }^{67} \mathrm{Ga}$ from Amberchrom $\mathrm{CG}-71 \mathrm{~cd}$ using $0.1 \mathrm{M} \mathrm{HCl}$.

dent to take the percentage removal of the impurity in question into account. As the percentage of Fe removals using the two different reducing agents were so similar, it was thought that a more definite decision could be made with regard to the most effective reducing agent should one take the $\mathrm{Zn}$ content in each product into account. This too, however, produced similar results.

It was finally decided that the most effective removal of impurities would be with the use of purified $\mathrm{TiCl}_{3}$ as reducing agent, as the $\mathrm{Fe}$ removal is marginally better than when $\mathrm{SnCl}_{2}$ was used as reducing agent, even though its removal of $\mathrm{Zn}$ is marginally less effective. Its ease of use in a hot cell environment, without requiring heat, was also a deciding factor in choosing $\mathrm{TiCl}_{3}$ over $\mathrm{SnCl}_{2}$ as reducing agent. Nevertheless, the use of both reducing agents with Amberchrom CG-161M resin produces a product that has vastly fewer impurities than the current production method used, making this a product that can be regarded as ultrapure.

\section{Conclusion}

Two alternate methods were tested and determined to be effective in the removal of $\mathrm{Fe}$, as well as $\mathrm{Zn}$, from ${ }^{67} \mathrm{Ga}$. When using either $\mathrm{SnCl}_{2}$ or purified $\mathrm{TiCl}_{3}$ as a reducing agent in the process and applying an Amberchrom CG-161M resin column instead of an Amberchrom CG-71cd resin column, the results produced are excellent, with a removal of $>99 \%$ of $\mathrm{Fe}$ and $>99.9 \%$ of $\mathrm{Zn}$ from the final product.

While these methods were successful under the production conditions of $30 \mathrm{mCi}{ }^{67} \mathrm{Ga}$, further tests using much higher activities of ${ }^{67} \mathrm{Ga}$ will be performed in the near future. 
[1] M. A. Green, M. J. Welch, J. Nucl. Med. Biol. 1989, 16, 435.

[2] F. Helus, W. Maier-Borst, J. Label. Compound Radiopharm. 1973, 317.

[3] T. N. van der Walt, F. W. E. Strelow, Anal. Chem. 1983, $55,212$.

[4] H. B. Hupf, J. E. Beaver, J. Appl. Radiat. Isot. 1970, 27, 1.

[5] S. R. Vallabhajosula, J.F. Harwig, W. Wolf, J. Nucl. Med. Biol. 1981, 8, 363.

[6] D. M. Taylor, V. R. McReady in Nuclear Techniques in Diagnostics Medicine (Ed: P. P. van Rijk), Martinus Nijhoff, Dordrecht, 1986, pp. 369.

[7] L. M. Freeman in Nuclear Medicine Annual, Lippincott Williams and Wilkens Publishers, Philadelphia, PA, 1999, pp. 165.

[8] D. J. Silvester, M. L. Thakur, Int. J. Appl. Radiat. Isot. 1970, $21,630$.

[9] J. R. Dahl, R. S. Tilbury, Int. J. Appl. Radiat. Isot. 1972, $23,431$.

[10] J. Steyn, B. R. Meyer, Int. J. Appl. Radiat. Isot. 1973, $24,369$.
[11] M. Vlatkovic, G. Paic, S. Kaucic, B. Vekic, Int. J. Appl. Radiat. Isot. 1975, 26, 377.

[12] R. D. Neirinckx, Int. J. Appl. Radiat. Isot. 1976, 27, 1.

[13] M. L. Thakur, Int. J. Appl. Radiat. Isot. 1977, 28, 183.

[14] F. W. E. Strelow, A. H. Victor, C. R. van Zyl, E. Cynthia, Anal. Chem. 1971, 43(7), 870.

[15] T. E. Boothe, E. Tavano, J. Munoz, J. Carrol, J. Label. Compound Radiopharm. 1991, 30, 108.

[16] M. K. Das, N. Ramamoorthy, Calcutta Ind. J. Nucl. Med. 1995, 10, 63.

[17] C. Naidoo, T. N. van der Walt, Appl. Radiat. Isot. 2001, $54,915$.

[18] K. M. El-Azony, Kh. Ferieg, Z. A. Saleh, Appl. Radiat. Isot. 2003, 59, 329.

[19] F. W. E. Strelow, Anal. Chim. Acta 1966, 34, 387.

[20] F. W. E. Strelow, A. H. Victor, Anal. Chim. Acta 1972, 59, 389.

[21] F.E.W. Strelow, C.H.S.W. Weinert, T. N. van der Walt, Talanta 1974, 21, 1183.

[22] C. Naidoo, M.Sc. thesis, University of Cape Town, 1998, p. 68. 